Z Gerontol Geriat 2019 · 52 (Suppl 1):S52-S61 https://doi.org/10.1007/s00391-018-01474-3 Received: 28 February 2018

Revised: 18 October 2018

Accepted: 23 October 2018

Published online: 9 November 2018

(c) The Author(s) 2018

CrossMark

\author{
Roland Kadefors ${ }^{1}(\mathbb{D}) \cdot$ Kerstin Nilsson $^{2} \cdot$ Per-Olof Östergren $^{3} \cdot$ Lars Rylander $^{2} \cdot$ \\ Maria Albin ${ }^{2,4}$ \\ ${ }^{1}$ Department of Sociology and Work Science, University of Gothenburg, Gothenburg, Sweden \\ ${ }^{2}$ Division of Occupational and Environmental Medicine, Lund University, Lund, Sweden \\ ${ }^{3}$ Division of Social Medicine and Global Health, Lund University, Lund, Sweden \\ ${ }^{4}$ Institute of Environmental Medicine, Karolinska Institutet, Stockholm, Sweden
}

\title{
Social inequality in working life expectancy in Sweden
}

pected to increase by 1.5 years for men and 2.1 years for women by 2060 [4]. Sweden does not have a fixed pension age. Since the pension system in built on life income, working more years will add significantly to pension benefits. In addition to the state pension, approximately $90 \%$ of Swedish employees have access to an employment pension, which is based on collective agreements between social partners.

Relying on economic incentives in order to bring about a longer working life in large parts of the labor market is built on the presumption that individuals have a free choice at what age they may retire; however, prospective retirees do not form a uniform group; they may be classified into four categories with respect to working into older age: (a) those who can and want to; (b) those who can but do not want to; (c) those who cannot but would like to, and (d) those who cannot, and do not want to [567]. Financial incentives to work could be attractive for those whose work ability is unaffected, for instance by health constraints. Therefore, such incentives may be relevant for individuals in the aforementioned categories (a) and (b), but less so for individuals in categories (c) and (d).

In a previous population study [8], this group showed that in the time period 2006-2011 the average working life exit age had moved upwards in almost all occupations, but that it differed between socioeconomic groups in both genders: "lost years" was defined as the number of years that people in a given occupation are expected to exit from the la- bor market before reaching age 65 years. Those in blue collar occupations ${ }^{2}$ exited working life earlier than those in almost all white collar occupations; there was a striking socioeconomic divide between blue and white collar workers in this respect. The difference between extremes in lost years before age 65 years $\left(\mathrm{SSYK}^{3}\right.$ 919 "Other sales and services elementary occupations” versus SSYK 231 “College, university and higher education teaching professionals") in 2011 amounted to approximately 4.7 years in men and 5.6 years in women.

An important question is what effects financial incentives may have in different socioeconomic groups. It is well known from studies in different economies that low-income groups tend to retire prematurely, even though they may face low pension benefits (e.g. [910]); however, socioeconomic determinants behind the decision to retire are manifold. Retirement norms may develop in different socioeconomic strata [11] and it has been shown that ill health may increase the likelihood of labor force exit into unemployment, disability pension and early retirement. Workers with low socioeconomic status, even after adjusting for ill health, have been found to be more likely to leave the labor force due to unemploy-

\footnotetext{
2 Here we use the traditional concept "blue and white collars" rather than the perhaps more modern alternative "manual workers and nonmanual employees".

${ }^{3}$ SSYK: Swedish Standard Classification of Occupations.
} 


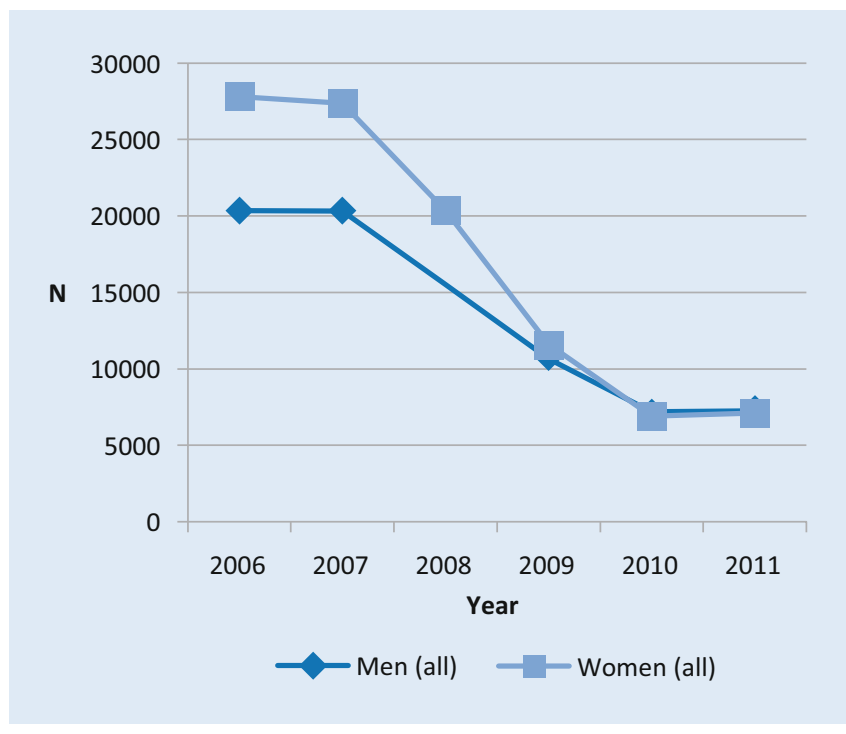

Fig. $1<$ The number of approved applications for disability pension in women and men following the policy change in 2006. (Data source: Swedish Social Insurance Agency) ment, disability pension and economic inactivity [12].

Even though work participation among older people is affected by many factors it is generally agreed that there is a strong influence of health on the age and the circumstances under which people retire. Those with health impairments have a heightened risk of prematurely dropping out of the labor force due to disability, unemployment or early retirement (e.g. [131415]). It is also well known that life expectancy as well as perceived health has a socioeconomic gradient. This gradient, as defined by educational level or by income percentile, has increased for life expectancy in Sweden during the last decades, as it has in other western European countries, while the socioeconomic gradient regarding self-reported health remained fairly constant over time. The match between work demands and individual capacity is an important determinant for premature exit from the labor market. In a public health survey conducted in the Stockholm area in Sweden, 18\% of the women and $20 \%$ of the men with only primary education stated that the physical work demands exceeded their capacity. The corresponding proportions for those with at least 3 years of university/college were $8 \%$ and $3 \%$ respectively [16]. This gradient may result from an excessive physical workload being most common in blue collar occupations, and a higher prevalence of concomitant disease reducing the work capacity in lower socioeconomic strata. Physical workload is the workplace exposure that contributes most to socioeconomic inequalities in health (e.g. [17]). Musculoskeletal disorders contribute over 50\% of the excess in disability retirement between manual workers and high-level non-manual workers, both among men and women [18].

Disability pension, which may be granted to applicants in the age range 30-64 years, has long been a common source of economic support preceding retirement. For instance, in 2009 out of those who retired at age 65 years $40.9 \%$ of the women and $30.1 \%$ of the men had been on disability pension the year before they retired [19]; however, in 2006 the Swedish government issued new guidelines limiting the opportunities for applicants to be granted disability pension on medical grounds. The results were striking: more than 530,000 persons were on disability pension in 2006 compared to approximately 373,000 in 2011 [20]. In a previous study it was found that following the changes in the disability pension regulations, the proportion of individuals who had chosen early age pension or employment pension increased, especially among those with a low level of education [21]. Early age pension can be drawn at free will by a person who has reached an age of 61 years; at age 65 years this tempo- rary status is converted to regular age pension

The present study aimed at identification of the socioeconomic effects of the policy changes instituted in 2006, by mapping the development of approved disability pension applications within different diagnosis groups, with respect to gender and occupational background of applicants. The study further analyzed the proportion of individuals in different occupations and with different socioeconomic characteristics who had chosen early age pension. In addition to socioeconomic groups identified by occupation, attention was also paid to the effect of country of birth on working life exits. ${ }^{4}$

\section{Method and material}

\section{Disability pension}

This investigation aimed at analyzing the development of approved applications for disability pension in the time period 2006-2011, following the changes instituted in 2006. The study was based on register data comprising the prevalence in the age group 55-64 years of disability pension and early age pension in different occupations. Special emphasis was on the differences between women and men. Swedish Social Insurance Agency data pooled with LISA ${ }^{5}$ statistics [1922] concerning approved disability pensions in 2006-2007 among persons in the age range 55-64 years were further analyzed with respect to socioeconomic patterns in the 10 occupations with the highest percentage of approved cases. This analysis was carried out using the 4-digit SSYK code, based on the International Standard Classification of Occupations (ISCO-88) [23]. The classification between blue and white collar occupations was undertaken using a proposed translation key developed by Statistics Sweden [24], based on a set of criteria includ-

\footnotetext{
${ }^{4}$ In the different parts of reporting, time periods vary to some extent. This depends on the availability of data, which differs depending on the data source.

${ }^{5}$ LISA: Longitudinal integration database for health insurance and labour market studies. lisa@scb.se.
} 
Z Gerontol Geriat 2019 · 52 (Suppl 1):S52-S61 https://doi.org/10.1007/s00391-018-01474-3

(c) The Author(s) 2018

R. Kadefors · K. Nilsson · P.-O. Östergren · L. Rylander · M. Albin

\section{Social inequality in working life expectancy in Sweden}

\section{Abstract}

Background. In Sweden there is a socioeconomic divide between white and blue collar workers with respect to the risk for premature exit from working life. Disability pension has long represented a major reason behind early exits.

Objective. The present investigation aimed at studying the effect on socioeconomic groups of new guidelines issued by the Swedish government in 2006, limiting the possibilities for applicants to be granted pension on medical grounds.

Material and method. The study was based on register data comprising the prevalence of disability pension and premature age pension in different occupations in the age group 55-64 years, comparing the years 2006 and 2011.
Results. It was found that in 2011 under the new guidelines, newly approved disability pensions had dropped by $70 \%$. Women were affected more than men. The drop in disability pensions affected applicants within the two most prevalent diagnosis groups, mental disorders (a drop by 58\%) and musculoskeletal disorders (a drop by $87 \%$ ). In the same time period, the percentage in the age range 55-64 years choosing premature age pension more than doubled. An increase in the number of premature age pensions was more common in blue collar occupational groups than in white collar workers. Occupation had a higher impact on working life expectancy than country of birth.

Conclusion. There are strong indications that many applicants, particularly blue collar workers, who had been unable to be granted disability pension under the new operational guidelines, instead choose premature retirement, a costly alternative for many individuals with already low pension benefits. The results indicate a tendency of passing on the societal costs of early labor market exits to various economic compensation arrangements, as well as to the individuals themselves.

Keywords

Retirement $\cdot$ Socioeconomic class · Disability pension · Health · Ancestry

\section{Soziale Ungleichheit in der Erwerbslebensdauer in Schweden}

\section{Zusammenfassung}

Hintergrund. In Schweden besteht eine sozioökonomische Disparität zwischen Arbeitern und Angestellten im Hinblick auf das Risiko eines vorzeitigen Ausscheidens aus dem Arbeitsleben. Die Erwerbsunfähigkeitsrente ist lange ein wesentlicher Grund für das vorzeitige Ausscheiden gewesen.

Zielsetzung. Untersucht werden sollten die Auswirkungen neuer Leitlinien der schwedischen Regierung aus dem Jahr 2006, welche die Möglichkeiten, aus medizinischen Gründen berentet zu werden, einschränken. Material und Methoden. Die Studie basierte auf Registerdaten, anhand derer sich die Jahre 2006 und 2011 hinsichtlich der Prävalenz von Erwerbsunfähigkeits- und vorzeitiger Altersberentung für in verschiedenen Berufen Tätige im Alter zwischen 55 und 64 Jahren vergleichen ließ.
Ergebnisse. Festgestellt wurde, dass im Jahr 2011 unter den veränderten Leitlinien die Anzahl neu genehmigter Erwerbsunfähigkeitsrenten um $70 \%$ gesunken war. Frauen waren stärker betroffen als Männer. Der Rückgang der Erwerbsunfähigkeitsrenten betraf Antragstellende innerhalb der beiden häufigsten Diagnosegruppen: psychische und muskuloskelettale Erkrankungen (Rückgang um 58 bzw. $87 \%$ ). Im gleichen Zeitraum hatte sich der Prozentsatz der Beschäftigten, der sich für die vorzeitige Altersrente entschieden hatte, mehr als verdoppelt. Mehr Arbeiter als Angestellte hatten sich für eine vorzeitige Altersberentung entschieden. Der Beruf hatte höheren Einfluss auf die Erwerbslebensdauer als das Geburtsland.

Fazit. Es gibt deutliche Anhaltspunkte dafür, dass viele Antragstellende, insbesondere
Arbeiter, die nach den neuen Leitlinien keine Erwerbsunfähigkeitsrente erhalten konnten, stattdessen auf den vorzeitigen Ruhestand setzen, für viele Menschen mit absehbar niedrigen Rentenleistungen eine mit finanziellen Einbußen verbundene Alternative. Diese Ergebnisse deuten auf eine Tendenz hin, die gesellschaftlichen Kosten eines frühen Ausscheidens aus dem Arbeitsmarkt in unterschiedliche ökonomische Entschädigungsvereinbarungen einfließen zu lassen und an die Betroffenen selbst weiterzugeben.

\section{Schlüsselwörter}

Ruhestand · Sozioökonomische Klasse . Erwerbsunfähigkeitsrente · Gesundheit · Herkunft ing nature of work, required length of education, and management responsibilities. It has been recognized that identification of socioeconomic status may take into account a person's main type of activity, occupation, occupational status (self-employed/employee) and be divided into upper non-manual employees, lower non-manual employees, manual workers and self-employed [25].

\section{Early age pension}

This population study aimed at an assessment of the proportion of individuals in different socioeconomic groups who had chosen early age pension in 2004 and in 2011. It was based on the Swedish national labor statistics covering all employees who had an occupational definition and who were 55-64 years of age in 2004 or in 2011. The individuals included in the study were classified in the age bracket 52-61 years in 2001 for the outcome age 55-64 years in 2004 and in 2011. In all, approximately 773,000 individuals were included in the study population for 2004, and 788,000 for 2011.

Occupations were identified according to the 3-digit SSYK code, with special consideration paid to differences between males and females. In the data processing the focus was on the largest occupational 


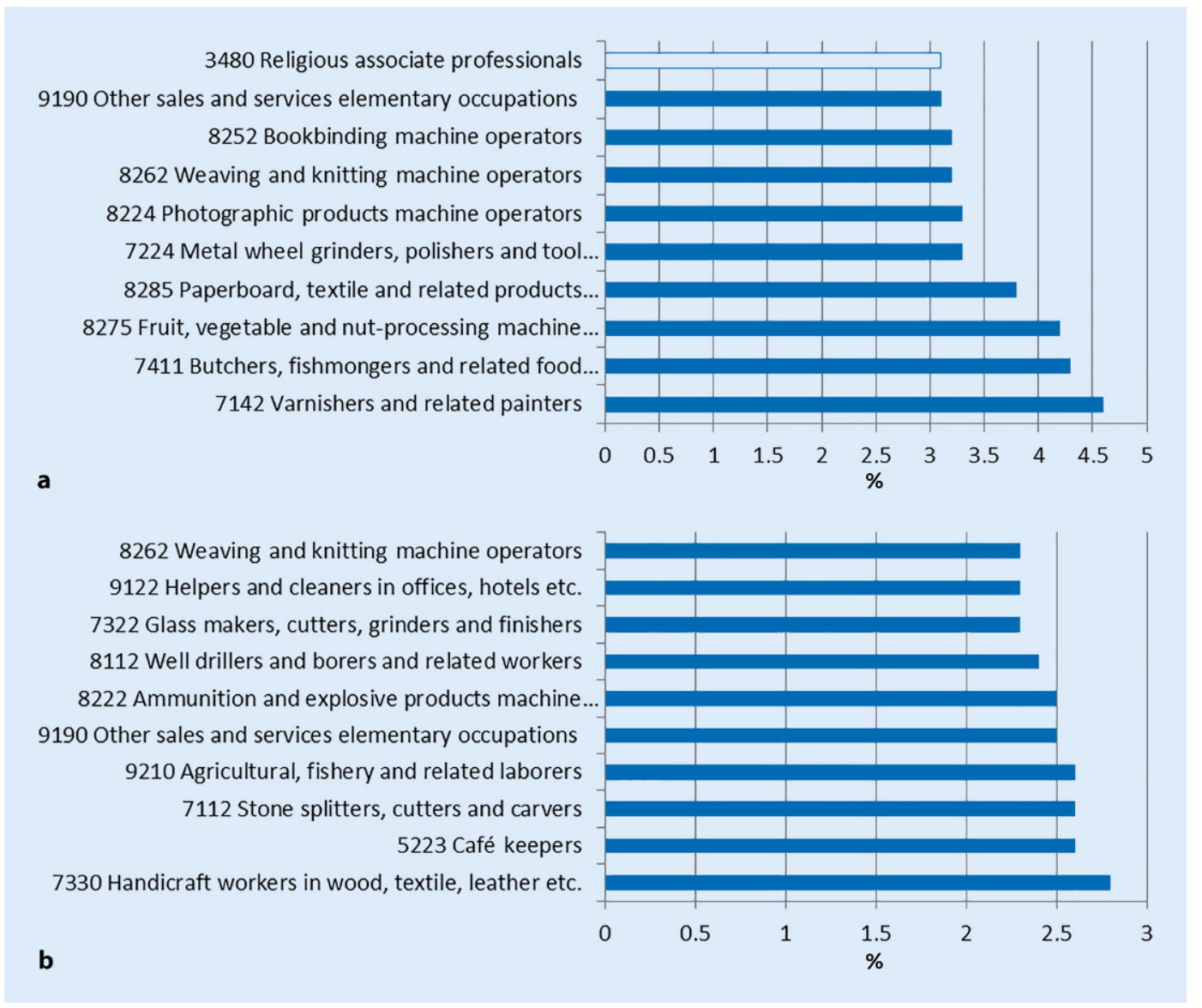

Fig. $2<a$, b The 10 occupations among Swedish women and men in the age range 50-64 years with the highest percentages of approved disability pensions before the policy change in 2006. Figures represent percentages of the total number of persons in the given age range, in the respective occupations. Note the different scales in a and $\mathbf{b}$. The only occupation to be identified as white collar in these statistics is in a SSYK4 3480: Religious associate professionals. White bars white collar, blue bars blue collar. (Data sources: Sjögren Lindqvist [19] and Statistics Sweden)

groups; hence, the 50 most common occupations in men and women were analyzed out of the 112 occupations listed according to SSYK 3. The group sizes in the study are large with at least 1000 observations in each group.

\section{Working life exit and ancestry}

In a previous report [8], the working life durations in different occupational groups were analyzed. In the present context, the same methodology was applied to account for the country of birth. The analysis was carried out as a population study employing methodology used in demographics to predict life expectancy at birth. Calculation of life expectancy in population statistics is based on data concerning the number of deaths in different age groups. Likewise, calculations of expected remaining working life duration are based on data of the exits from working life. These calculations comprise death, disability pension and long-term sick leave preceding disabil- ity pension. The study was based on the Swedish national labour statistics, covering all employees who had an occupational definition in November 2006. Another inclusion criterion was to be in the age 35-64 years during the measurement period 2007-2010. Exiting before age 65 years means that a person faces lost years in working life. At age 35 years, there remains 29.5 years for an individual to reach 65 years, the Swedish pension norm. Hence, the number of lost years is 29.5 years minus the expected number of years entailed in the analysis. For a more in-depth description of the method employed, see [8]. In the presentation of the ancestry statistics, the socioeconomic identification key based on occupation is applied again [24], but in this case SSYK 1, the highest aggregation level; this is to ascertain relevant group sizes.

\section{Results}

\section{Disability pension}

The effect of the policy change in 2006 was dramatic. In the time period 2006-2011, the total number of approved applications annually was reduced progressively from 48,176 to 14,369 , i.e. by $70.0 \%$. For women, the reduction was $74.4 \%$ and for men $64.3 \%$ (• Fig. 1). Within the two major diagnostic groups according to the International Classification of Diseases (ICD-10-SE); F00-F99 (mental disorders) and M00-M99 (musculoskeletal illnesses), the reduction amounted to $58 \%$ and $87 \%$ respectively. In women the reductions amounted to $64.9 \%$ for mental disorders, and $91.1 \%$ for musculoskeletal disorders; in men the corresponding reductions were 48.8 and $90.0 \%$, respectively.

Who were the people who had been granted disability pension before the policy change? Fig. 2 a, b shows the 10 occupations with the highest percentage of 
Table 1 Prevalence of early age pension in socioeconomic groups in 2004 and 2011 (55-64-yearolds)

\begin{tabular}{llllllll} 
& $\begin{array}{l}\mathbf{2 0 0 4} \\
\text { White } \\
\text { collar }\end{array}$ & $\begin{array}{l}\text { Blue } \\
\text { collar }\end{array}$ & $\begin{array}{l}\text { Difference } \\
\text { blue-white }\end{array}$ & $\begin{array}{l}\mathbf{2 0 1 1} \\
\text { White } \\
\text { collar }\end{array}$ & $\begin{array}{l}\text { Blue } \\
\text { collar }\end{array}$ & $\begin{array}{l}\text { Difference } \\
\text { blue-white }\end{array}$ \\
\hline Women & 1.27 & 1.93 & 0.66 & 4.57 & 6.03 & 1.46 \\
& $N=30$ & $N=16$ & $p>0.05$ & $N=31$ & $N=14$ & $p<0.01$ \\
Men & 2.69 & 2.02 & -0.67 & 6.01 & 6.32 & 0.31 \\
& $N=30$ & $N=32$ & $p<0.01$ & $N=33$ & $N=35$ & $p>0.05$
\end{tabular}

$N$ the number of occupational groups identified as white or blue collar, where the number of individuals exceeded 1000

\begin{tabular}{|c|c|c|c|c|}
\hline & $\begin{array}{l}2004 \\
(\%)\end{array}$ & $\begin{array}{l}2011 \\
(\%)\end{array}$ & $\begin{array}{l}\text { Increase } \\
(\%)\end{array}$ & $\begin{array}{l}\text { Increase } \\
\text { number }\end{array}$ \\
\hline Women & 1.7 & 5.5 & 3.8 & 15,564 \\
\hline Men & 2.5 & 6.4 & 3.9 & 15,000 \\
\hline
\end{tabular}

the population sample in the age span 50-64 years. The mean percentages in women and men were $3.61 \%$ and $2.49 \%$ $(p<0.001)$, respectively, showing that it was significantly more common among women than men to be on disability pension before the change in governmental policies. It was found that among men, all 10 of the occupations singled out were characterized as blue collar, and among women 9 out of 10. In fact, extending the figures by another 10 high risk occupations also entails solely more new blue collar occupations for men and women.

\section{Early age pension}

- Table 1 shows the early pension prevalence in 2004 and 2011, and probabilities for the differences between blue and white collar occupations as evaluated by t-tests. In 2004, there was no significant difference among women between white and blue collar workers in the most common occupations; however, it was more common among men in white collar occupations than in blue collar occupations to have chosen early age pension. In 2011, this difference had disappeared but among women blue collar now showed significantly higher percentages than white collar occupations.

The prevalences of early age pension in the age group 55-64 years were compared in 2004 and 2011, before and after the change in disability pension policies, in the 50 most common occupations. What possible effects of the restrictions could be found in the early age pension statistics? - Table 2 shows that the prevalence of persons in the age range 55-64 years who were on early age pension in 2004 and 2011 had increased, for men and women alike. The increase amounted to 30,564 persons.

The analysis of the change in different occupations showed that in all 50 occupations studied in men and women, early age pension was more common in 2011 than in 2006. - Figs. 3 and 4 show the change in age pension prevalence among women and men, also applying the socioeconomic criteria identifying occupations as blue or white collar. For instance, for the two extremes in • Fig. 3 (SSYK 231 and SSYK 913), the prevalence of early age pension in women in 2006 was $0.96 \%$ and $2.05 \%$, respectively and in 2011 the corresponding numbers were $2.21 \%$ and $8.00 \%$. This means that for SSYK 913 (helpers in restaurants) there was an increase of 5.96\%; for SSYK 231 (college, university and higher education teaching professionals) the prevalence increase was a mere $1.24 \%$.

Some occupations were mixed blue and white collar; this means that according to the translation key [24], an SSYK 3 occupation may contain both blue and white collar SSYK 4 occupations. In women, out of the 50 occupations analyzed, the 10 occupations with the lowest increase in percentage change were all white collar, whereas out of the 10 most affected occupations 9 were blue collar or mixed (mean values of blue and white collar occupations: 6.03 and 4.57, respectively; $p<0.01$ ).

Among men, 9 out of the 10 with the smallest changes were white collar and 1 was blue collar. Out of the occupations with the highest changes, 9 were blue, and 1 white collar (mean values of blue and white collar occupations: 4.42 and 3.19 , respectively; $p<0.01$ ).

\section{Working life exit and ancestry}

- Tables 3 and 4 show average lost years in working life before age 65 years in groups according to occupation ${ }^{6}$ and geographical area of birth. It is seen that the socioeconomic divide prevails; the number of lost years is higher among blue collars in all groups, irrespective of land of birth. In all occupational groups, the Swedish born exit work later than those of different ancestry, but there is no consistent pattern with respect to geographical areas outside Sweden.

\section{Discussion}

\section{Disability pension}

The result of the study showed that the change in disability pension policies in 2006 affected blue collars more than white collars, and women more than men. These findings comply in part with the results in earlier studies [1921], noting that many of the most affected occupations before the change could be characterized as manual jobs with low requirements of formal education. These characteristics are part of the criteria applied by Statistics Sweden [24] in the development of a key linking SSYK code to socioeconomic group. In the present analysis, these affected occupations were classified as blue collar.

The high occurrence among blue collar workers when it comes to accepted applications for disability pension be-

\footnotetext{
${ }^{6}$ Note: SSYK 6 (Skilled agricultural and fishery workers) was left out due to low numbers in some cells.
} 
231 College, university and higher education teaching professionals

122 Production and operations managers

249 Psychologists, social work and related professionals

223 Nursing and midwifery professionals

213 Computing professionals

222 Health professionals (except nursing)

214 Architects, engineers and related professionals

235 Other teaching professionals

245 Writers and creative or performing artists

244 Social science and linguistics professionals (except social work

247 Public service administrative professionals 242 Legal professionals 414 Library and filing clerks

344 Customs, tax and related government associate professionals

131 Managers of small enterprises 123 Other specialist managers

241 Accountants

311 Physical and engineering science technicians 232 Secondary education teaching professionals

234 Special education teaching professionals

243 Archivists, librarians and related information professionals

342 Business services agents and trade brokers

346 Social work associate professionals.

312 Computer associate professionals

323 Nursing associate professionals

331 Pre-primary education teaching associate professionals

415 Mail carriers and sorting clerks

324 Life science technicians

341 Finance and sales associate professionals

919 Other sales and services elementary occupations

827 Food and related products machine operators

322 Health associate professionals (except nursing)

829 Other machine operators and assemblers

$821 \mathrm{Metal}$ and mineral products machine operators

233 Primary education teaching professionals

$343 \mathrm{Administrative} \mathrm{associate} \mathrm{professionals}$

411 Office secretaries and data entry operators

912 Helpers and cleaners

513 Personal care and related workers

512 Housekeeping and restaurant services workers

828 Assemblers

412 Numerical clerks

413 Stores and transport clerks

422 Client information clerks

419 Other office clerks

932 Manufacturing laborers

522 Shop and stall salespersons and demonstrators

421 Cashiers, tellers and related clerks

832 Motor vehicle drivers

913 Helpers in restaurants


\section{.}

0.00

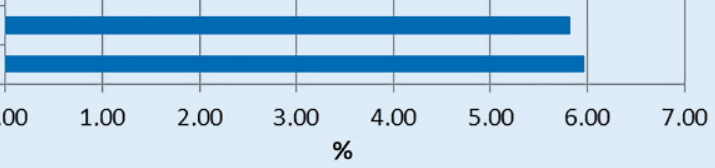

Fig. $3<$ The change in age pension percentages 2006-2011 among Swedish women in the 50 most common occupational groups, also applying the socioeconomic criteria identifying occupations at the SSYK3 level. White bars white collar, blue bars blue collar, striped bars mixed blue and white collar. (Data source: Statistics Sweden) 
231 College, university and higher education teachers 235 Other teaching professionals

214 Architects, engineers and related professionals

247 Public service administrative professionals

232 Secondary education teaching professionals

122 Production and operations managers

233 Primary education teaching professionals

312 Computer associate professionals

515 Protective services workers

213 Computing professionals 222 Health professionals 828 Assemblers

249 Psychologists, social work and related professionals

829 Other machine operators and assemblers 242 Legal professionals

513 Personal care and related workers 245 Writers and creative or performing artists

824 Wood products machine operators 933 Transport labourers and freight handlers

413 Stores and transport clerks

814 Wood processing and papermaking plant operators

241 Business professionals

342 Business services agents and trade brokers

722 Blacksmiths, tool makers and related trades workers

821 Metal and mineral products machine operators 131 Managers of small enterprises 123 Other specialist managers

723 Machinery mechanics and fitters

121 Directors and chief executives

343 Administrative associate professionals

311 Physical and engineering science technicians

611 Market gardeners and crop growers

914 Doorkeepers, newspaper and package deliverers 919 Other sales and services elementary occupations

419 Other office clerks

816 Power production and related plant operators

341 Finance and sales associate professionals

712 Building frame and related trades workers

721 Metal moulders, welders, sheet metal and related trade.

833 Agricultural and other mobile plant operators

713 Building finishers and related trades workers

812 Metal processing plant operators

932 Manufacturing labourers

345 Police officers and detectives

522 Shop and stall salespersons and demonstrators

415 Mail carriers and sorting clerks

714 Painters, building structure cleaners and related trades.

724 Electrical and electronic equipment mechanics and fitters

832 Motor vehicle drivers

825 Printing, binding and paper products machine operators
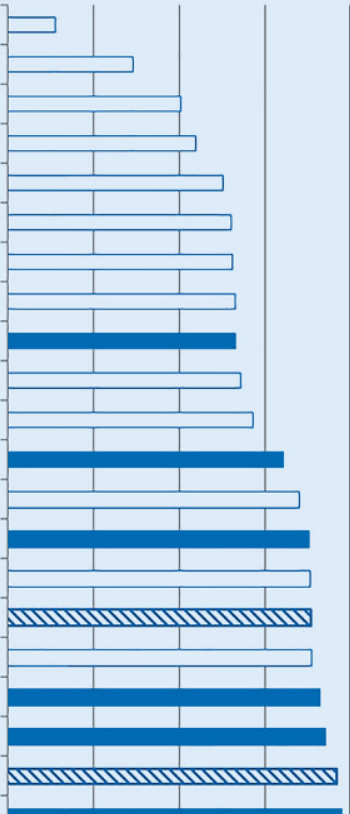

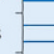

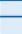

$-$
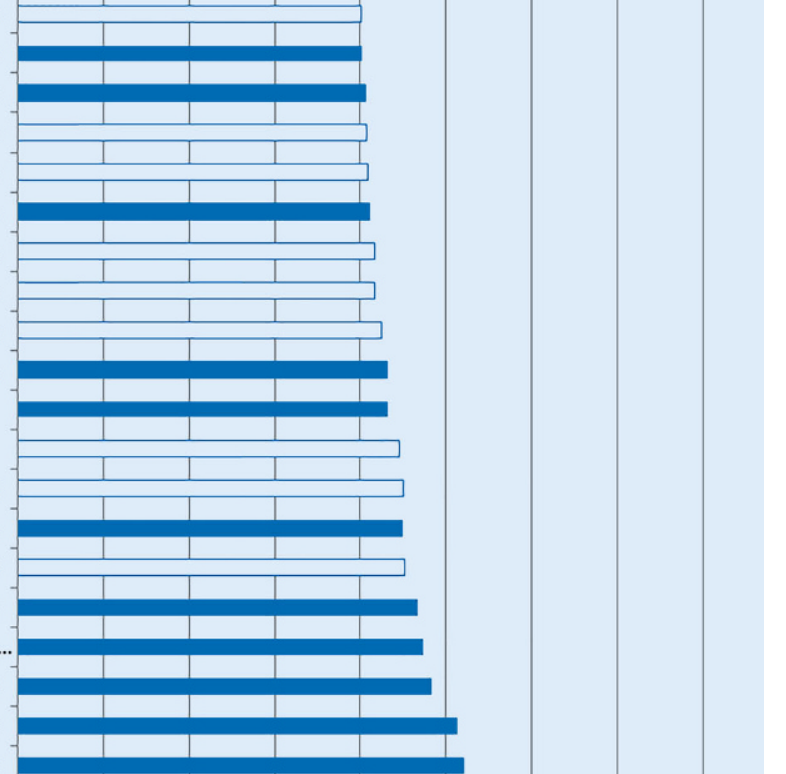$$
-
$$

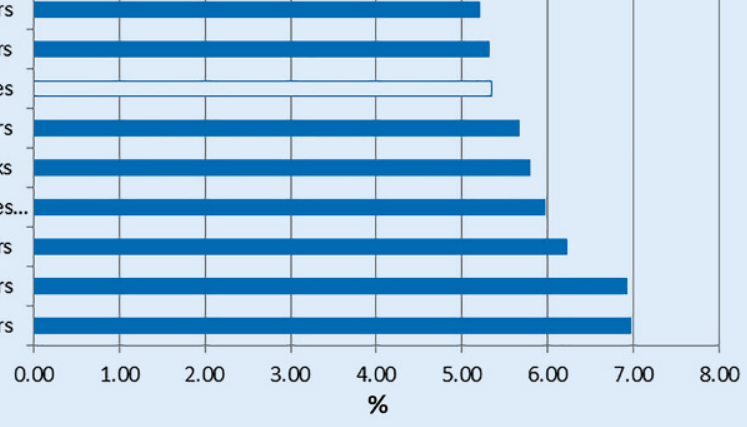

Fig. $4<$ The change in age pension percentages 2006-2011 among Swedish men in the 50 most common occupational groups, also applying the socioeconomic criteria identifying occupations at the SSYK3 level. White bars white collar, blue bars: blue collar, striped bars mixed blue and white collar. (Data source: Statistics Sweden) 
Table 3 Lost years in working life before age 65 years according to ancestry (land of birth) and occupation in 2011 (women). (Data source: Statistics Sweden)

\begin{tabular}{|c|c|c|c|c|c|}
\hline SSYK 1 & $\begin{array}{l}\text { Blue/ } \\
\text { white } \\
\text { collar }\end{array}$ & Sweden & Nordic & Europe & $\begin{array}{l}\text { Outside } \\
\text { Europe }\end{array}$ \\
\hline $\begin{array}{l}\text { Legislators, senior officials and } \\
\text { managers }\end{array}$ & White & 0.39 & 0.56 & 0.85 & 0.46 \\
\hline Professionals & White & 0.47 & 0.52 & 0.67 & 0.65 \\
\hline $\begin{array}{l}\text { Technicians and associate profes- } \\
\text { sionals }\end{array}$ & Mixed & 0.62 & 1.12 & 0.86 & 1.24 \\
\hline Clerks & Mixed & 0.89 & 1.16 & 1.00 & 1.62 \\
\hline $\begin{array}{l}\text { Service workers and shop sales } \\
\text { workers }\end{array}$ & Blue & 1.30 & 1.62 & 1.93 & 1.74 \\
\hline Craft and related trades workers & Blue & 1.28 & 1.80 & 2.48 & 1.73 \\
\hline $\begin{array}{l}\text { Plant and machine operators and } \\
\text { assemblers }\end{array}$ & Blue & 1.59 & 2.49 & 3.56 & 2.61 \\
\hline Elementary occupations & Blue & 2.40 & 3.06 & 3.59 & 2.51 \\
\hline
\end{tabular}

Table 4 Lost years in working life before age 65 years according to ancestry (land of birth) and occupation in 2011 (men). (Data source: Statistics Sweden)

\begin{tabular}{|c|c|c|c|c|c|}
\hline Occupational group & $\begin{array}{l}\text { Blue/ } \\
\text { white } \\
\text { collar }\end{array}$ & Sweden & Nordic & Europe & $\begin{array}{l}\text { Outside } \\
\text { Europe }\end{array}$ \\
\hline $\begin{array}{l}\text { Legislators, senior officials and } \\
\text { managers }\end{array}$ & White & 0.38 & 0.92 & 0.39 & 0.69 \\
\hline Professionals & White & 0.49 & 0.53 & 0.69 & 0.65 \\
\hline $\begin{array}{l}\text { Technicians and associate profes- } \\
\text { sionals }\end{array}$ & Mixed & 0.59 & 1.09 & 0.90 & 0.98 \\
\hline Clerks & Mixed & 1.40 & 1.99 & 1.82 & 1.35 \\
\hline $\begin{array}{l}\text { Service workers and shop sales } \\
\text { workers }\end{array}$ & Blue & 1.38 & 2.59 & 1.78 & 1.58 \\
\hline Craft and related trades workers & Blue & 0.98 & 1.69 & 2.09 & 1.39 \\
\hline $\begin{array}{l}\text { Plant and machine operators and } \\
\text { assemblers }\end{array}$ & Blue & 1.27 & 1.94 & 2.76 & 1.55 \\
\hline Elementary occupations & Blue & 2.71 & 3.04 & 3.39 & 2.38 \\
\hline
\end{tabular}

fore policy change complies with statistics from the Swedish Social Insurance Agency with respect to sick leave incidence [20]. - Fig. 5 shows the numbers of sick leave per 1000 employees for the year 2006 in different occupations, classified according to SSYK 1. It is clear that the same distinction gradient between blue and white collar jobs exists with respect to sick leave as well as concerning disability and early age pension, further illustrating previous conclusions with respect to the importance of social determinants on health and retirement generally [2627].

\section{Early age pension}

In the present study it was found that following the 2006 change in disability pension policies, in 2011 there was a significant increase in the number of older persons who had chosen to take early age pension. This development concerned blue collars more than white collars, and women more than men.

For an older person who has been denied disability pension on medical grounds, there are a limited number of possible options, including continued work despite poor health, unemployment, sick leave, relying on relatives, or, as a last resort, social security. In this situation, it is understandable that early age pension may be seen as a solution, even though taking retirement pension before age 65 years negatively affects lifelong pension benefits. It is a costly alternative for most people, but for those who may have acquired few pension points (perhaps worked few years, part time or with low salary) it may be seen as an economically acceptable way out.

A closer analysis of the white collar data reveals that a particularly high prevalence of persons on early age pension was found among male managers, for instance SSYK 121, directors and chief executives, and SSYK 131, managers of small enterprises $(5.1 \%$ and $5.2 \%$, respectively, compared to $2.5 \%$ across all occupations). Among women, the corresponding figures were $2.7 \%$ and $2.1 \%$, compared to $1.7 \%$ across all occupations. There seems to be a difference between male and female behavior in this respect.

\section{Working life exit and ancestry}

It was found that the socioeconomic divide between blue and white collars exists across all groups irrespective of the country of origin. Those born outside Sweden tended to exit work earlier than Swedes. Based on statistics concerning disability pensions in 2006-2007 in groups of persons living in Sweden but with different ancestry, it has been reported that those who had immigrated to Sweden had a higher probability than the Swedish born to be on disability pension [19]; however, it was found that when controlling for occupation, the differences between groups of different origins decreased; among men, the probability of exiting due to disability pension became independent of country of birth, and also among women, the differences were markedly reduced. The results of this study comply largely with these findings; the occupation tended to have a larger influence on working life exits than ancestry.

\section{Sociodemographic differences and the policy change}

The gender differences observed in the present report with respect to disability pension before the policy change in 2006 reflects that in Sweden, periods with long 


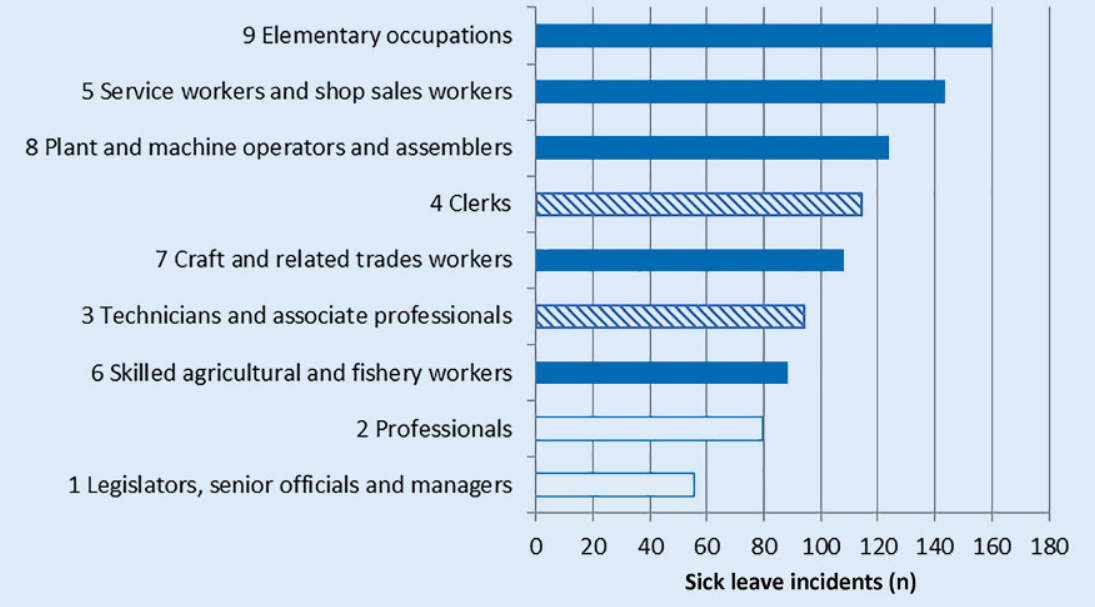

Fig. $5 \Delta$ The number of sick leave incidents per 1000 employees in 2006 in different occupational groups according to SSYK 1, for women and men combined. White bars white collars, blue bars blue collars, striped bars mixed. (Data source: Swedish Social Insurance Agency)

( $>60$ days sick leave) became more common among women than among men in the early 1980 s, and the female to male ratio increased sharply up almost twofold from the early 1990s and onwards [28]. The Swedish labor market is highly gendered and the difference in female to male sick leave is largely driven by higher sickness absence in the occupations which are predominantly female (in healthcare and education). Women in the health sector reported the highest prevalence of low control in the Swedish Work Environment Survey in the early 1990s [29], and this structural difference prevails [30]. The results with respect to country of origin comply with statistics concerning sick leave in socioeconomic groups, showing that insured immigrants have a slightly higher risk of sickness benefit compared to Swedish born people. This difference was primarily explained by the fact that immigrants usually work in the service industry, healthcare and sales industry, which are occupations with relatively high levels of sickness absence [31]. Women had higher risk than men, particularly high among immigrants from regions suffering from armed conflicts.

\section{Conclusion}

This study showed that the guidelines introduced by the Swedish government curtailing the possibilities for applicants

\section{Compliance with ethical guidelines}

Conflict of interest. R. Kadefors, K. Nilsson, P.-O. Östergren, L. Rylander and M. Albin declare that they have no competing interests.

This article does not contain any studies with human participants or animals performed by any of the authors.

The supplement containing this article is not sponsored by industry.

Open Access This article is distributed under the terms of the Creative Commons Attribution 4.0 International License (http://creativecommons.org/licenses/by/ 4.0/), which permits unrestricted use, distribution, and reproduction in any medium, provided you give appropriate credit to the original author(s) and the source, provide a link to the Creative Commons license, and indicate if changes were made.

\section{References}

to be granted disability pension affected women more than men, and blue collar more than white collar occupations. There was an apparent flow among those denied disability pension to early age pension, in particular in blue collars. The findings indicate that the budgetary savings of disability pensions arrived at by the government were at least to some extent transferred to the individual persons. The socioeconomic divide between white and blue collars prevailed also with respect to working life exits in groups of different ancestry. The restrictive terms for awarding disability pension, combined with the proposed higher age for full retirement benefits, and the strong economic benefits available to those who work longer, will increase the social inequalities. There is a need to take into account the effect on different socioeconomic groups of the changes currently being introduced in the welfare systems.

\section{Corresponding address}

\section{Prof. Roland Kadefors, PhD}

Department of Sociology and Work Science, University of Gothenburg

Box 705, 40530 Gothenburg, Sweden

roland.kadefors@socav.gu.se

Acknowledgements. We gratefully acknowledge the contribution provided by Örjan Hemström, Statistics Sweden.
1. OECD Stat Extracts (2017) Short-term labour market statistics. https://stats.oecd.org/Index.aspx? DataSetCode=STLABOUR. Accessed 5.11.2018

2. Swedish Pension Age Commission of Inquiry (2013) Åtgärder för ett längre arbetsliv [Measures for a longer working life]. Final ReportSOU:2013:25 (In Swedish, with a summary in English)

3. Government Offices of Sweden (2017) Pensionsgruppens överenskommelse om långsiktigt höjda och trygga pensioner [The Pension Group Agreement concerning Increased and Secure Pensions in the Long Term]. https:// www.regeringen.se/4af042/contentassets/ cf23cff3664b49da8b3c34b8a85ec83a/ pensionsgruppens-overenskommelse-om-langsiktigt-hojda-och-trygga-pensioner.pdf. Accessed 5.11.2018 G20 indicators. OECD Publishing, Paris (https:// read.oecd-ilibrary.org/social-issues-migrationhealth/pensions-at-a-glance-2017_pension_ glance-2017-en\#page13)

5. Nilsson K (2012) Why work beyond 65? Discourse on the decision to continue working or retire early. Nord J Work Life Stud 2(3):7-28 (http://www.nordicwl.com/nilsson-2012-whywork-beyond-65-discourse-on-the-decision-tocontinue-working-or-retire-early/)

6. Nilsson K (2016) Conceptualization of ageing in relation to factors of importance for extending working life. Scand J Public Health 44:490-505 (http://journals.sagepub.com/doi/pdf/10.1177/ 1403494816636265)

7. Nilsson K (2017) The influence of work environmental and motivation factors on seniors' attitudes to an extended working life or to retire. A cross sectional study with employees $55-74$ years of age. Open J Soc Sci 5:30-41 (http://file.scirp.org/ pdf/JSS_2017071013594273.pdf)

8. Kadefors R, Nilsson K, Rylander L, Östergren P-O, Albin M (2018) Occupation, gender and work life exits. A Swedish population study. Ageing Soc 38(7):1332-1349. https://doi.org/10.1017/ S0144686X17000083

9. Munnell AH, Webb A, Chen A (2016) Does socioeconomic status lead people to retire too
4. OECD (2017) Pensions at a glance 2017. OECD and 
soon? Report 16-14. Center for Retirement Research, Boston

10. Micheel F, Roloff J, Wickenheiser I (2010) The impact of socioeconomic characteristics on older employees' willingness to continue working in retirement age. Comp Popul Stud 35(4):869-902

11. LindbeckA, Nyberg S, Weibull J (2003) Social norms and welfare state dynamics. J Eur Econ Assoc 1:533-542

12. Schuring $M$, Robroek $S$, Otten $F$, Arts $C H$, Burdorf $A$ (2013) The effect of ill health and socioeconomic status on labor force exit and re-employment: a prospective study with ten years follow-up in the Netherlands. Scand J Work Environ Health 39(2):134-143

13. Wurm S, Engstler H, Tesch-Römer C (2009) Ruhestand und Gesundheit. Nova Acta Leopoldina NF 105:81-192. https://www.researchgate. net/publication/265057617_Ruhestand_und_ Gesundheit. Accessed 3 Sept 2017

14. Hasselhorn HM, Rauch A (2013) Perspektiven von Arbeit, Alter, Gesundheit und Erwerbsteilhabe in Deutschland. Bundesgesundheitsblatt Gesundheitsforschung Gesundheitsschutz 56(3):339-348

15. van den HeuvelS, de Wind A (2015) Domain: Health and health-related behaviour. In: Hasselhorn HM, Apt W (eds) Understanding employment participation of older workers: creating a knowledge base for future labour market challenges. Research Report. Federal Ministry of Labour and Social Affairs (BMAS) and Federal Institute for Occupational Safety and Health (BAuA), Berlin (http://www. jp-demographic.eu/about/fast-track-projects/ understanding-employment)

16. Center of Occupational and Environmental Medicine, Stockholm County Council (2017) Arbetshälsorapport Stockholms län 2016. Work Health Report, County of Stockholm 2016 (In Swedish)

17. Leinonen T, Pietiläinen $O$, Laaksonen $M$, Rahkonen O, Lahelma E, Martikainen P (2011) Occupational social class and disability retirement among municipal employees - the contribution of health behaviors and working conditions. Scand J Work Environ Health 37(6):464-472

18. Polvinen A, Laaksonen M, Gould R, Lahelma E, Martikainen $P$ (2014) The contribution of major diagnostic causes to socioeconomic differences in disability retirement. Scand J Work Environ Health 40(4):353-360

19. Sjögren Lindqvist G (2011) Sjukersättning och yrke [Disability pension and occupation]. Swedish Pension Age Commission of Inquiry (SOU 2011:05). www.sou.gov.se/wp-content/uploads/2013/05/ a73f3fb7.pdf. (In Swedish). Accessed 5.11.2018

20. Swedish Social Insurance Agency (2017) Statistik om sjuk- och aktivitetsersättning [Disability and sickness pension statistics]. https:// www.forsakringskassan.se/statistik/sjuk/sjukoch-aktivitetsersattning (In Swedish). Accessed 5.11.2018

21. Nilsson K, Östergren P-O, Kadefors R, Albin M (2016) Has the participation of older employees in the workforce increased? Study of the total Swedish population regarding exit from working life. Scand J Public Health 44(5):506-516. https://doi.org/10. $1177 / 1403494816637262$

22. Sjögren Lindquist G, Wadensjö E (2010) Arbetsmarknaden för de äldre [The labour market for older people]. Studier i Finanspolitik 2009/7, Finanspolitiska Rådet (In Swedish)

23. International Labour Organization (1990) Geneva: International Standard Classification of Occupations (ISCO-88)
24. Thell M (2015) Rekommenderad indelning av arbetare och tjänstemän utifrån SSYK 96 kod [Recommended classification of blue and white collar workers, based on SSYK 96 code]. (Yrkesregistret, ES/FRS). Statistics Sweden, Stockholm (In Swedish)

25. Polvinen A (2016) Socioeconomic status and disability retirement in Finland. Department of Public Health, University of Helsinki, Helsinki (Ph.D. dissertation)

26. Marmot M, Allen J (2014) Social determinants of health equity. Am J Public Health 104(suppl.4):S517-S519

27. Robroek SJ, Schuring M, Croezen S, Stattin M, Burdorf A (2013) Poor health, unhealthy behaviors, and unfavorable work characteristics influence pathways of exit from paid employment among older workers in Europe: a four year follow-up study. Scand JWorkEnviron Health 39(2):125-133. https://doi.org/10.5271/sjweh.3319

28. Swedish Social Insurance Agency (2015) Sjukskrivningar 60 dagar eller längre [Sick leaves 60 days or longer]. Social insurance report 2015:1. https://www.forsakringskassan.se/ wps/wcm/connect/d7d4b78e-39fa-4c2f-bed9ade979b5ff23/socialforsakringsrapport_2015_ 1.pdf?MOD $=$ AJPERES $\& C V I D=\& C A C H E=N O N E \&$ CONTENTCACHE=NONE. Accessed 5.11.2018

29. Theorell T, Oxenstierna G, Westerlund $H$ (2004) Ju färre vi är tillsammans... Sjukskrivningsmönster vid strukturella förändringar. [The fewer we are... Sick report patterns in structural change]. Report, Public Health Agency of Sweden 2004:15, pp.222. https:// www.folkhalsomyndigheten.se/contentassets/ f91aeb1812f64e1da19b14125bf7f72d/hogasjukfranvaron-sanning-konsekvens.pdf. Accessed 5.11.2018

30. Swedish Work Environment Authority (2016) The Work Environment Survey 2015 Report 2016:2. https://www.av.se/globalassets/filer/ statistik/arbetsmiljon-2015/arbetsmiljostatistikarbetsmiljon-2015-rapport-2016-2.pdf. Accessed 5.11.2018

31. Swedish Social Insurance Agency (2017) Sjukfrånvaro efter invandring [Sickness leave among immigrants]. Social insurance report 2017:7 (in Swedish, with a summary in English). https://www.forsakringskassan.se/ wps/wcm/connect/95884afa-4dbf-49d6-8a427ad23fcf1803/socialforsakringsrapport-2017-07. pdf?MOD=AJPERES\&CVID. Accessed 5.11.2018 